\title{
Orientation, Parent Engagement, Tutoring, Summer Programs, and College Support: How a City is Helping Immigrant Students
}

\author{
Kerri Evans, PhD, LCSW ${ }^{*}$, Anna Coney, BA ${ }^{2}$, Amina Musa ${ }^{3}$ \\ ${ }^{1}$ Assistant Professor, Social Work University of Maryland, Baltimore County, 1000 Hilltop Cir. Baltimore, Maryland, United States. \\ ${ }^{2}$ Graduate, University of Maryland, Baltimore County, United States. \\ ${ }^{3}$ Student, University of Maryland, Baltimore County, United States.
}

\section{Article Details \\ Article Type: Research Article \\ Received date: $25^{\text {th }}$ October, 2021 \\ Accepted date: $28^{\text {th }}$ December, 2021 \\ Published date: $03^{\text {rd }}$ January, 2022}

*Corresponding Author: Kerri Evans, PhD, LCSW, Assistant Professor, Social Work University of Maryland, Baltimore County, 1000 Hilltop Cir. Baltimore, Maryland, United States. E-mail: kerrieva@umbc.edu

Citation: Evans, K., Coney, A., \& Musa, A. (2022). Orientation, Parent Engagement, Tutoring, Summer Programs, and College Support: How a City is Helping Immigrant Students. J Ment Health Soc Behav 4(1):153. https://doi.org/10.33790/ jmhsb1100153

Copyright: (C2022, This is an open-access article distributed under the terms of the Creative Commons Attribution License 4.0, which permits unrestricted use, distribution, and reproduction in any medium, provided the original author and source are credited.

\begin{abstract}
One in four children in U.S. schools are part of an immigrant family, and we need to ensure that there are enough, and culturally sensitive services available to meet their needs and help them succeed educationally. Using a qualitative document analysis framework, the authors deductively coded more than 110 websites to assess the services available to immigrant students in a city in a Mid-Atlantic state of the United States. The results indicate that services included English as a second language services $(n=33)$, tutoring $(n=23)$, parent engagement activities $(n=11)$, summer programs $(n=11)$, college access programs $(n=10)$, and orientation programs $(n=9)$. Together the agencies and schools offer many programs that are reminiscent of collective impact models. We provide recommendations for future research and practice.
\end{abstract}

Keywords: Immigrant; Student; Services; Educational Success

\section{Introduction}

One in four children in United States (US) schools are part of an immigrant family [1]. Hadjar and Scharf [2] suggest that, due to Western societies' emphasis on meritocracy, education functions as an important tool for immigrants to achieve success in accordance with this ideology. As a result, ensuring immigrants' access to equitable and inclusive education is an essential factor to their integration and achievement in the U.S. The needs of immigrant students, as well as the immigrant populations coming to the U.S. are constantly changing. For example, Vietnamese refugees were the biggest group entering the U.S. after the Fall of Saigon in 1975, which is similar in many ways to the Afghans arriving to the U.S after troops pulled out of Afghanistan in 2021 [3]. Over the past decade we have seen a variety of crises at the southern border such as large numbers of unaccompanied children [4], families being forcibly separated under the Trump Administration [5], and currently there are restrictions on arrivals leading to encampments in Mexico [6] and Haitians waiting on shores [7]. Across nationalities and immigration statuses, however, the literature has consistently established that educational attainment is a major predictor of success later in life for people for immigrants in the U.S. [8-13]. In this study, we assessed the services available to immigrant students in a city in a Mid-Atlantic state of the United States, in order to analyze ways in which we can improve service diversity through a collective impact model to help students to the highest extent possible.

\section{Strengths Based Approach}

Research on newcomers often focuses on needs and deficits due to the many challenges newcomers face upon arrival to a new country [14-16]. However, it is necessary to recognize the strengths of newcomers as well [17]. A strengths based perspective emphasizes shared knowledge [18,19] and collaboration [18]. Additionally, a strengths based approach encourages social workers to acknowledge the strengths, abilities, proficiencies, and potential of clients [18]. Some teachers and school staff see the problems and challenges of working with immigrant students first and focus on these rather than using a strengths-based approach [20].

We recognize and acknowledge the importance of interacting with and distributing information on immigrant communities using a strengthsbased perspective to contribute to their empowerment processes. Therefore, our literature review will highlight the educational needs of immigrant students, and this will be complimented by our results section which focuses on the services provided by this city in order to meet these needs and assist newcomer students in reaching their academic potential in the U.S.

\section{Literature Review}

\section{The Value of Education and how it Helps Immigrant Families}

In the U.S., education is seen as both 1) a vehicle for social capital and access to greater opportunities in life, and 2) something that protects our youth from trouble. Education fosters the empowerment processes of immigrants by providing opportunities to build successful outcomes, such as through language learning, enhancing cognitive skills, building relationships, and learning about U.S. values and culture [9]. Promotion of these skills allow immigrants to exercise greater control over their futures in the U.S.. Equally important, education plays an integral role in one's employment and career growth, as Carnevale et al. [8] reported that postsecondary education beyond high school is necessary for about $65 \%$ of all jobs. Consequently, education supports immigrants' empowerment and integration to the U.S., and also provides resources and tools to build long-term stability and success [9]. Evans and colleagues [10] also found this to be true in that educational attainment was a significant predictor of self-sufficiency for immigrant youth aging out of foster care. Lastly, Sleijpen and colleagues [13] found that education enabled refugee youth to move across levels of social stratification. 
Relatedly, education is also a protective factor. Research shows that low educational attainment leads to delinquency and crime and that failing high school increases likelihood of involvement with the prison system [21]. Similarly, low school engagement or sense of belonging in school is associated with higher levels of youth violence [22]. Therefore, parents in low-income neighborhoods internationally often feel that education is "the way off the street" [23].

Many immigrant children face challenges that make it difficult to fully participate in education. These include language and cultural barriers [24], challenges with academic adjustment and expectations in the U.S. [25], unresolved historical trauma [26,27] , as well as differing priorities and goals between family members who may want children to work vs. schools who may push for access to college [28,29]. Additionally, level of education, language ability, lack of familiarity with US school systems, and socioeconomic status of parents greatly influences the parent's availability to assist their children with homework and educational needs [30,31,32]. Given the multiple challenges that immigrant students face, educational attainment and access to freely attend and participate in school is of utmost importance to immigrants in the U.S. educational system.

\section{Academic Achievement for Immigrant Students}

Research shows a variation in rates of academic achievement among immigrant students and children of immigrants [33,34]. For example, Rodríguez et al. [35] found that native students performed better in science and mathematics. However, De Feyter et al. [36] revealed that children of immigrants showed better attendance, higher grades, and higher scores on standardized reading and math tests in comparison to their peers from native families. In addition to this variation, a paradox is noted in educational research around immigrant students, which states that despite apparent challenges immigrant students face during their transition to the U.S., they tend to do about as well or better than their native peers [37]. This paradox is more pronounced for boys in comparison to girls, as well as children of Asian and African immigrants in contrast to other groups [38]. In Jeong\&Acock's, [39] study of East Asian and Mexican immigrant families, results showed that disparities between rates of academic achievements of immigrants were based on the characteristics of the child and their family. Achievement was found to be largely due to familial resources, which demonstrates that access to resources plays an important role in immigrant students' achievement [39]. Additionally, the contrast in research findings related to immigrant academic achievement may be explained by several different variables that are critical in determining an immigrant student's achievement, such as cultural dissonance between the beliefs and values of one's home and school, ethnic discrimination at school, and psychological well-being [40]. Due to the variety and number of such variables, immigrants' academic experiences are likely to vary greatly.

Research shows that different factors are important determinants in educational outcomes for immigrant students and children of immigrants. For example, their parents' lack of English proficiency and knowledge of U.S. cultural and educational systems can pose challenges to immigrant students [39]. Jung \& Zhang, [41] found that English language proficiency of immigrant parents is an important contributor to the academic success, cognitive development, and English language proficiency of their children. Additionally, discrimination negatively influences academic performance of immigrant students [40]. Legal status of immigrant parents also plays a role in academic outcomes; however, use of social services may decrease the negative effects a parent's legal status has on their child's education [42]. The numerous external factors involved in influencing academic outcomes for immigrant students shows that more effort and attention is crucial to accommodate for these factors in school settings, such as training for staff and teachers, engagement and outreach efforts for parents, and cultural awareness activities to assist immigrant students in building positive academic outcomes.

\section{Methodology}

The research team conducted a document analysis of websites for local schools, organizations, nonprofits, and local businesses to search for available services and answer the research question: What educational support services are available to immigrant students in the city? A document analysis is a form of qualitative research methods that uses a systematic process to review existing written works (in this case, websites) in place of interview transcripts [43]. The primary search engine was Google search, and 113 different agencies/ programs were located that advertised services for immigrants within the metro area using search terms such as: education, school, immigrant, refugee, asylee, service, and [city name]. Our exclusion criteria included the following concepts: newspaper articles written before 2018 were not included in case the agency was no longer in service; agency addresses were searched on a map and we only included those within the geographic bounds of the city; and we excluded agencies that are open to all people as the purpose of the study is to better understand resources developed for and targeted specifically to work with immigrant students and families. However, if the website was presented in multiple languages, we did include the agency/program with the thought that translation of a website was a significant effort towards inclusion of English Language Learners, many of whom are immigrants.

After extensive training, research assistants completed deductive coding on all 113 websites looking for content to fit six different areas related to school services as determined by researcher experience and a literature review on the subject. The six themes included: summer bridge programs, orientation to a new school, parent engagement in school, tutoring and academic support (which included tangible supplies to help students in school), English as a Second Language programs, as well as resources on college programs and access (ie. applications/scholarships). The research assistants took detailed notes from each website about programs and assistance that touched upon any of these areas, including direct quotes when relevant. The research team met weekly during the coding phase to ensure everyone was understanding content on the websites, and assigning the appropriate codes. The university IRB approved this protocol.

Secondarily, we looked to analyze the types of organizations providing services to immigrants, and which services they provide. In order to do so, we coded organizations using the following process: Organizations coded as school-oriented include services at individual schools, district-wide initiatives, community college and university run programs, and anything housed in a school building. Government run programs included those affiliated with the Mayor's, or the Governor's office. For all other organizations, we searched the website to determine the reach of the organization and program: international, national, or local community based services.

\section{Characteristics of the City's Immigrants}

In order to understand the results of the document analysis, it is important to fully understand the immigrant community living in the city. While the focus of this study is immigrant students in $\mathrm{K}-12$ education, we include statistics on all immigrants because the research supports the idea that parents are influential in the academic trajectory of their children [30-32,39,41].

The city of focus for this study has a population of roughly 600,000 residents. More than $15 \%$ of residents in the state are foreign-born [44], but only eight percent of residents in the city identified as foreign-born [45]. Nonetheless, immigrants in the city are a diverse population. Of the foreign-born population in the city, $41 \%$ are from Latin America, 26\% are from Asia, 19\% are from Africa, 11\% are immigrants from Europe, $2 \%$ are from North America, and 1\% are from Oceania. In terms of racial identity, $34 \%$ of immigrants are White, $32 \%$ are Black or African American, 21\% are Asian, less 
than one percent are American Indian and Alaska Native, or Native Hawaiian and Other Pacific Islander. Eleven percent of immigrants self-identified as some other race and two percent are two or more races. In terms of ethnicity, $26 \%$ are Hispanic or Latino Origin (of any race), and $19 \%$ are White alone, not Hispanic or Latino. Almost half $(41 \%)$ are naturalized citizens, $52 \%$ identify as male and $48 \%$ identify as female. Only about half $(46 \%)$ of immigrants in the city are in a married-couple family, and $51 \%$ are living in other households [46].

The age demographics of immigrants in the city are as follows: $1 \%$ are under age $5,5 \%$ are aged $5-17$ years, $9 \%$ are aged 18 to 24 years, $47 \%$ are aged $25-44,15 \%$ are aged $45-54$ years, $11 \%$ are aged 55 to 64 years, $7 \%$ are aged 65 to 74 years, $4 \%$ are aged 75 to 84 years, and $1 \%$ are aged 85 years or older. The median age of immigrants in the city is 39 years [46]. According to City Public Schools [47], just over seven percent of students are English Language Learners. Of all the immigrant students in the city, only $1 \%$ attend nursery school/ preschool, $15 \%$ of immigrant students are enrolled in K-8 and 13\% are currently enrolled in highschool. According to the census data, there is a much higher number $(71 \%)$ of the immigrants enrolled in college or graduate school, which encompasses people of all ages.

\begin{tabular}{|l|l|}
\hline School Enrollment & Percent \\
\hline Nursery School \& preschool & $1 \%$ \\
\hline $\begin{array}{l}\text { Elementary School (grades } \\
\text { K-8) }\end{array}$ & $15 \%$ \\
\hline High School (grades 9-12) & $13 \%$ \\
\hline College or graduate school & $71 \%$ \\
\hline \\
Table 1. Educational Demographics of Immigrant Students in \\
the City \\
\hline
\end{tabular}

In terms of immigrants aged 25 and older in the city, there is a pretty even split among educational attainment. For example, 20\% have not completed a high school degree, and another $19 \%$ have only acquired a high school diploma or equivalent. On the other hand, $18 \%$ of students have attended some college or received an associate degree, and $19 \%$ have completed and received a bachelor's degree. Only $24 \%$ have received either a graduate or professional degree. Regardless of education level, $84 \%$ of immigrant households have a head of household who is working in the local labor market [46].

\begin{tabular}{|l|l|}
\hline Educational Attainment & Percent \\
\hline Less than high school graduate & $20 \%$ \\
\hline $\begin{array}{l}\text { High school graduate (includes } \\
\text { equivalency) }\end{array}$ & $19 \%$ \\
\hline $\begin{array}{l}\text { Some college or associate's } \\
\text { degree }\end{array}$ & $18 \%$ \\
\hline Bachelor's degree & $19 \%$ \\
\hline $\begin{array}{l}\text { Graduate or professional } \\
\text { degree }\end{array}$ & $24 \%$ \\
Table 2. Educational Attainment of Immigrant Parents in \\
the City
\end{tabular}

\section{Results}

In the city, we found that websites discussed educational services targeted for immigrant students including information on: English as a second language, tutoring, parent engagement, summer bridge programs, college access, and orientation programs. In graph 1, below, we visually display the number of organizations that offer each type of educational service for immigrant students discussed in this paper.

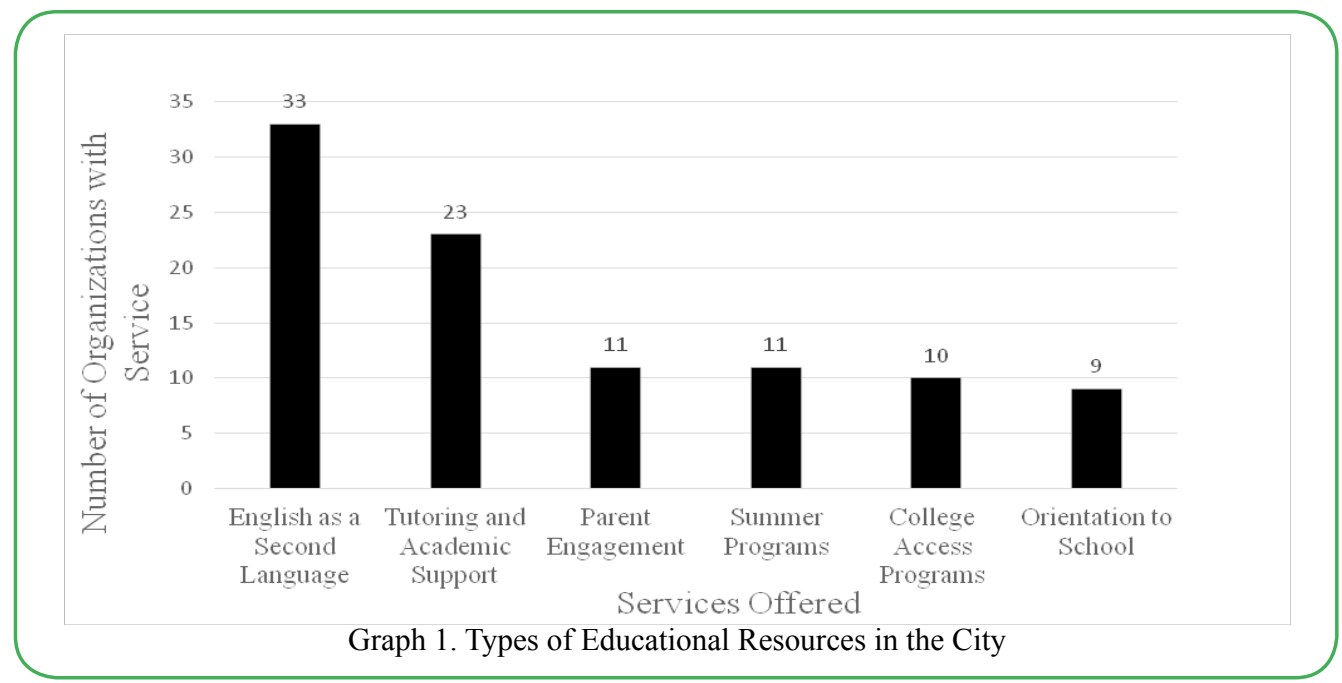




\section{English as a Second Language}

Many ESL supports are offered to students and families through the public school system. The city public school system uses their school website to disseminate information about ESOL school services and important information for ESOL students and families, such as the assessment process for ESOL school services. They also provide online/PDF learning resources for ESOL students and families. The provision of ESOL services to newcomer students in the city depends on the student's English language proficiency, which is “... determined by the Kindergarten W-APT ${ }^{1}$ or the WIDA Screener and the annual WIDA ACCESS..."

Thirty-three sources mention ESOL services on their websites. Of these sources, many organizations offered ESOL classes and instruction to newcomers that focused on teaching and strengthening English skills, with some specifying the specific levels of English at which the classes were taught, such as... "Low Beginning, High Beginning, Low Intermediate, High Intermediate, Advanced/ Civics, Conversation for Advanced Speakers." Additionally, one organization discussed the variety of reasons that one might take an ESL course, by mentioning goals such as “...earn[ing] a college academic certificate or degree, develop[ing] their language skills for personal enrichment, or obtain[ing] a GED." Some organizations offer after-school programs to help students learn English, while others offer ESOL classes in a virtual format.

Other organizations apply a holistic approach to their delivery of ESOL services. For example, one organization incorporates English language learning (ELL) into sport activities, as they “... integrate English language learning into our coaching, practice designs, and soccer activities, while also providing direct English language support off the field, as resources allow." Similarly, other organizations use art engagement as a vehicle for ELL. Another program utilizes a structural approach, as they stated their work "improves student achievement through the design, implementation and assessment of the English for Speakers of Other Languages Program (ESOL)." These approaches allow newcomers to engage in English practice in a social and cultural setting, instead of isolating learning activities solely to a structured setting, such as a classroom. In regard to eligibility requirements, some ESOL services require a fee to participate. Additionally, some services target specific populations of newcomers, such as refugees, asylees, and women.

\section{Tutoring and Academic Support}

Twenty-three organizations provide tutoring or academic support services to immigrant students in the city, either in-person or online. One school offers early literacy tutoring and another organization targets adults, as they provide instructional services to help prepare for GED exams. Multiple organizations, both schools and community agencies, offer after-school programs. Common goals identified for after school programs include "...homework help, [building] social skills, and... improving English language skills", as well as providing cultural enrichment activities. Similar to after-school programs, some schools and organizations offer educational clubs, such as literacy and STEM clubs.

Another program includes academic support to help students build life skills, increase their scores on exams and assessments, and overcome language barriers that may be present during learning. There is an organization focused on "creating quality learning spaces in formal schools and informal education settings, such as community-based education and accelerated learning programs for children who have missed years of schooling." Although many organizations provide services that are primarily focused on tutoring, numerous organizations provide comprehensive services that support positive outcomes in addition to academic achievement, such as enrichment activities, mentoring programs, and college preparation services.
One school offers services to promote school readiness for young students. Two programs specifically target Latinx youth and families. Another program noted that services are for students who are 5-20 years old. Some organizations specifically targeted refugee children.

\section{Parent Engagement}

Nine programs intentionally include parent engagement services within their suite of services. Of these, seven are school based programs that encourage parents and caregivers to partake in the school community and their children's learning. During the COVID-19 pandemic, one school hosted virtual discussions with parents to help teach them about "create[ing] a home environment that is conducive to learning." One organization hosted a program solely for parents, and another was open to both parents and teachers to allow for open discussion and facilitate parental participation in school. One local organization offers a nine week workshop in Spanish in which "parents learn how to navigate the educational system, and how to take an active role in their child's education." Additionally, one school offers summer programs that include family engagement and resources for home. Here, parents are given the opportunity to apply for leadership roles, serve on committees, and volunteer in classrooms, sports and clubs.

\section{Summer Programs}

Eight agencies discuss summer educational programs. Two are camp-style programs targeted towards younger children and include a curriculum. One of these is only open to refugee children and the other is open to all children, but specifically noted they do not discriminate against immigrants. Another agency offers a structured literacy program for children in grades one through five. The school district offers summer school, and immigrant students are eligible to take summer courses as a repeat course, or to get ahead on credits. Two agencies have summer tutoring available to all children. Lastly, one organization works with immigrant high school students to pair them up for summer internships and professional experiences that will help prepare them for life after graduation.

\section{College Access}

Access to higher education is important for immigrant and refugee children as they prepare for their futures, and these programs assist families with the logistics and knowledge needed to navigate the college process in the US $[48,49]$. Eight programs provide resources to help navigate newcomers through the college process. These programs include workshops, college fairs, and mentoring programs which aim to "facilitate immigrant students access to higher education and postsecondary opportunities." One program brings in college and scholarship representatives to give students the opportunity to ask one on one questions. Another program targets their workshops to both parents and students with culturally relevant materials in Spanish and English. These materials highlight the "importance of high school completion, higher education, financial aid scholarships and college preparation." Additionally, two of the organizations focus on providing scholarships to students in need of financial aid.

Mentoring programs with a focus on high school and college preparation and support are another key service found in the document analysis. One organization stated that their mentoring services were meant "...to enlighten students about the college application process, financial aid, course selection, homework help, employment opportunities, and other topics." One mentoring program is hosted by the local community college in an effort to increase enrollment. A similar theme of preparation for higher education was found in other programs, such as academic coaching, with the purpose of helping "...students [learn] how to pursue [city name omitted] City academic programs and prepare children for higher education." One of the mentoring programs had eligibility prerequisites for students, such as age and GPA requirements, and current or former status as an ESOL learner. 


\section{Orientation to Schoo}

Eight organizations identify orientation to school as a service or goal of the organization. Some organizations support students with early steps in the process such as enrolling students in schools, choosing schools and classes, or learning about ESOL services. One school utilized a case management framework to connect with families, even during the pandemic, by using coordinators to talk with families, answer questions about navigating the school, and connect families to resources. Other schools and organizations focus on preparation services for high school and some even include a focus on colleges, such as "...workshop [s] for students and parents [to promote] early planning and knowledge about post-secondary options." One program focuses specifically on helping "schoolaged youth develop the knowledge and skills required for academic success and positive integration." The findings show that services meant to aid individuals in orienting to school prioritize helping students enroll in the school, decision making, connecting them to related services, and developing skills and knowledge about U.S. education. Very few services targeted specific populations or had certain eligibility requirements, however one program is specifically targeted towards Latinx families.

\section{Types of Organizations and Educational Services Provided}

Throughout the analysis we found that many different organizations were offering services, and therefore the section below shares descriptive statistics and patterns among the type of organization and the types of services provided by organizations. Table 3, below, displays the findings from an analysis that describes the type of organization (school, government organization, community-based organizations, national, and international organizations) for each of the 97 different educational services described in Graph 1 above. It should be noted that of the 113 agency websites reviewed, there were 61 organizations that did not provide educational services (ie. they offered housing, legal assistance, food pantry, etc) and therefore these organizations are not listed below as the research question specifically relates to educational services.

Additionally, the analyses found that 14 organizations were religiously affiliated, in that they identify a house of worship, or the name of a religion, in the name of either the organization or the specific program.

\begin{tabular}{|c|c|c|c|c|c|c|}
\hline & $\begin{array}{l}\text { Public School/ } \\
\text { Higher } \\
\text { Education }\end{array}$ & $\begin{array}{l}\text { Government } \\
\text { Programs }\end{array}$ & $\begin{array}{l}\text { Community } \\
\text { Based } \\
\text { Organizations }\end{array}$ & $\begin{array}{l}\text { National } \\
\text { Programs and } \\
\text { Nonprofits }\end{array}$ & $\begin{array}{l}\text { International } \\
\text { Organizations }\end{array}$ & Total \\
\hline $\begin{array}{l}\text { English as a } \\
\text { Second Language }\end{array}$ & 15 & 2 & 12 & 3 & 1 & 33 \\
\hline $\begin{array}{l}\text { Tutoring and } \\
\text { Academic Support }\end{array}$ & 8 & 1 & 10 & 2 & 2 & 23 \\
\hline $\begin{array}{l}\text { Parent } \\
\text { Engagement }\end{array}$ & 7 & & 4 & & & 11 \\
\hline Summer Programs & 6 & & 4 & 1 & & 11 \\
\hline College Access & 1 & & 8 & 1 & & 10 \\
\hline $\begin{array}{l}\text { Orientation to } \\
\text { School }\end{array}$ & 4 & & 2 & 2 & 1 & 9 \\
\hline $\begin{array}{l}\text { Total Educational } \\
\text { Services }\end{array}$ & 41 & 3 & 40 & 9 & 4 & 97 \\
\hline
\end{tabular}

\section{Discussion and Implications}

In this section, we will compare and contrast our findings with other literature on the topics at hand, and provide implications for research, practice, and policy. We will also discuss the ways that these services work together to provide holistic care and assistance to immigrant families.

\section{English as a Second Language}

The literature strongly supports the importance of the English language skills for non-native speakers' success and integration into U.S. society [50,51]. Lack of English proficiency has been attributed to many problems related to the well-being of immigrants such as economic, social, and health challenges [52,53]. For example, Youdelman [53] states that individuals who are less proficient in English encounter language barriers that result in lower quality healthcare. Therefore, it is great to see that ESOL classes are widely offered across the city, and that they include varying levels in order to reach a broader group as not all immigrants have the same English proficiency. ESL classes should be offered in the school setting, in the community, and virtually in order to meet the needs of both students and their families. ESL services should also be available to adults as the literature suggests that parents' knowledge can heavily influence the academic outcomes of children [30-32,39,41].

\section{Tutoring and Academic Support}

Many newcomer students face barriers and challenges when adjusting to a new school, such as language barriers, gaps in schooling, and lack of knowledge about culture [16,54]. Our results show that organizations utilize many different approaches to support newcomer students, which reveal important implications for students, parents, school professionals, and policy makers. For example, child and adolescent newcomers may arrive in the U.S. with limited education due to migration patterns or availability and access ability in their home country $[16,55]$. Supportive services that are targeted towards helping newcomer students fill the gaps in their education can be helpful as the academic experiences of immigrant students may differ from other students. Evans and colleagues (accepted), found that immigrant students want more tutoring than is available.

Equally important is the social and emotional well-being of students in schools. Therefore, participating in a mentoring program upon arrival to the U.S. may facilitate an immigrant student's acculturation process [56,57]. Additionally, mentoring programs serve as a useful tool that provides a comprehensive approach for a student's welcoming process to a new school, such as helping the newcomer to make social connections, learn about available clubs and programs, etc [57].

Other useful approaches may be adult education programs. Adult 
newcomers may arrive in the U.S. with limited education that impacts their ability to participate in other important processes during their integration process, such as getting a job. Refugees can access formal cultural orientation classes $[58,59]$ but other immigrants are not given this resource and therefore, more services are needed at the community level to educate parents on the educational policies (e.g. mandatory attendance, graduation requirements), and norms for parental engagement.

\section{College Access and Mentoring}

College mentorship programs play a critical role in promoting school engagement and facilitating academic success [48]. Research shows that there is no systematic way to find mentors and the schools often lack individuals with knowledge on guiding undocumented or DACA students through the college process. Therefore, individuals on the college institution side are often the ones providing support, albeit outside of their job description [48]. Our results show that multiple agencies are helping newcomer students to access college, and providing mentoring throughout this process, which is a strength within the city.

\section{Orientation to School}

Although the city schools offer specific resources to help enroll and integrate newcomer students into schools, students could benefit from additional supportive services from schools or independent organizations. Orientation is an ongoing process, and does not stop once the student is enrolled in the school. Case management services can aid in helping and advocating for newcomer students when challenges or barriers arise [60]. Programs that focus on building positive social support, such as peer mentoring, can help the newcomer learn about school culture and student resources directly from the students themselves [57,61]. Additionally, most organizations that offered orientation offered it for students and did not mention parents and the orientation that they need. Parents and caregivers may need assistance in learning about the school system as well, for example, understanding the school's grading system, requirements for graduation, or how school busing systems operate. Interventions such as the WeGrad program at Arizona State University [62] are an example of the ways we can build capacity and knowledge of immigrant parents. Services that involve parents in the initial orientation process can demonstrate the importance of their long-term involvement in their child's education.

\section{Types of Organizations and Educational Services Provided}

In Graph 1 above, we see that the most provided services include English as a Second Language classes/supports $(n=33)$, and other academic tutoring or supports $(\mathrm{n}=23)$. This is not surprising to find the research that supports the need for academic achievement in order to succeed in the U.S. is plentiful $[8-13,21,22]$. In Table 3 the types of organizations are in a matrix with the types of services. This chart shows that the majority of educational services are provided by schools $(n=41)$ and by community-based organizations $(n=40)$ as opposed to government organizations or national/international organizations. The schools being most involved makes sense to the authors as schools have the most knowledge and most closely related mission to helping students

succeed. Many immigrants fear government organizations if they are lacking legal status, or have been treated unfairly in the past [63]. Yoshikawa et al., [64] note that community based organizations and religious organizations provide much of the service needs to immigrant families in the US. We see this as an explanation to the high number of community based organizations found in this study. Local community-based organizations have spent time working to build rapport and trust in immigrant communities, and once this relationship is built the immigrant may return to that organization first in times of academic need.

\section{Limitations}

This study has limitations. First, if a website was in multiple languages only the English content was coded and it is possible that some relevant content was missed as some websites did not appear to translate all content word for word. Secondarily, we found Facebook pages for organizations that seemed to fit our criteria, but these often had very minimal information, and sometimes there was no actual website to find more information on the program/organization. Third, informal resources were unable to be accounted for due to our methodology. For example, there was a news article about a great community advocate that seemed to be meeting critical client needs, but she was not an organization, and therefore we could not find any additional information to analyze for this study. However, we are recommending that future studies include interviews so that these sources could be identified and included for a more holistic picture. Lastly, and most importantly, this study is a document analysis of website materials and there is a need to dig deeper and understand the resources that are available and used by immigrant families but that might not be listed online.

\section{Future Directions}

While the services provided in this city seem to be numerous and welcoming towards immigrant and refugee students, there are always opportunities to improve and offer more if we want immigrant students to achieve the best possible outcomes. Here we will discuss a few recommendations including: more intentional collaboration, specific summer bridge programs to make entering the school easier, and enhancing the rigor of the research through a mixed methods approach.

Kania and Kramer [65] coined the term collective impact when they established a model for social change that described largescale social change can only be possible when there is cross-sector coordination. The earliest examples of collective impact focus on the U.S. public school system because of the fact that amazing teachers can make progress for one child, or in one classroom but that systemwide progress at improving our educational system and decreasing the achievement gap has not happened [65] and this model is still used when looking at education [66], including models specific to advancing Latinx students [49] and immigrant students [67]. The findings from this study show that there are 97 different programs serving immigrants across the city. This could be a great opportunity to collaborate more intentionally and develop a strategic plan for advancing the academic (including social and emotional) well-being of immigrant students in this city.

Bridge programs are designed to help new students acclimate to school norms and help learn basic content and language skills with the hopes of higher success rates during the school year $[68,69,70]$. Our analyses did not find any programs specifically focusing on preparing children for school or bringing them up to grade level, and so this may be an additional service that is needed for students in the city. We acknowledge that immigrants arrive in the U.S. throughout the entire year, and so not all students would benefit from this type of program, yet it could be beneficial to many.

In order to build upon the research started in this study, we suggest a few things. First, qualitative interviews are needed with service providers to understand what other resources are available that were not mentioned on websites. Additionally, interviews can enable us to understand more informal support systems in the community, which are a valuable resource, and can also help us to understand when an advertised service is not actually available to clients due to waitlists, staff shortages, accessibility, or other problems. Furthermore, examining services offered at the individual school level, in addition to the district level, would provide a more detailed representation of the network of services and resources provided to newcomer students. It could be interesting to map the different agencies and services to better understand gaps across the city.

JMHSB, an open access journal 


\section{Conclusion}

Research demonstrates that immigrants have high educational aspirations [2]. Additionally, immigrants place great value on education and have high expectations for their children's education $[23,71,72]$. Our study aimed to identify and analyze the scope of educational resources and services available to newcomer students in the city. The research team utilized qualitative research methods in the form of a document analysis to review and categorize services available to immigrants.

Our results demonstrate strengths and weaknesses in regards to the availability of services offered to newcomer students in the city. There are a multitude of ESL services available to immigrants as well as tutoring and academic support for newcomers that can help to address the educational achievement gaps for immigrant students. However, our analyses show a lack of available services in programs that promote school preparation and the social and emotional needs of children who are new to the U.S. school environment. Lastly, while there are many services available we are unsure to what extent they work together to meet common needs. Collective impact models are most successful when stakeholders are intentionally brought together and sitting at the same table to have these conversations.

Our recommendations for future research involve qualitative interviews with service providers to gain a more comprehensive understanding of services available to newcomer students in the city. In addition, we suggest diving in deeper to understand what is offered at individual schools as compared with at the school district level. While these recommendations are based upon the analysis of this specific city, we think that the idea of holistic and well-rounded services should be applied to various geographic areas and therefore we encourage other areas to complete similar analyses of their own services.

Funding: No funding was received for this project

Disclosure statement: There are no conflicts of interest to declare

\section{References}

1. Figlio, D., Guiliano, P., Marchingiglio, R., Özek, U., \& Sapienza, P. (2021, April 30). Do immigrants harm native students academically? Brookings Institute: https:/www. brookings.edu/blog/brown-center-chalkboard/2021/04/30/doimmigrants-harm-native-students-academically/

2. Hadjar, A., \& Scharf, J. (2019). The value of education among immigrants and non-immigrants and how this translates into educational aspirations: a comparison of four European countries. Journal of Ethnic \& Migration Studies, 45(5), 711734. https://doi-org/10.1080/1369183X.2018.1433025

3. National Museum of American Diplomacy. (2021). The fall of Saigon (1975): The bravery of American diplomats and refugees. https://diplomacy.state.gov/u-s-diplomacy-stories/ fall-of-saigon-1975-american-diplomats-refugees/

4. Negroponte, D. V. (2014). The surge in unaccompanied children from Central America: A humanitarian crisis at our border. Brookings Institute. https://www.brookings.edu/blog/upfront/2014/07/02/the-surge-in-unaccompanied-children-fromcentral-america-a-humanitarian-crisis-at-our-border

5. Southern Poverty Law Center. (2020). Family separation under the Trump administration - A timeline. https://www. splcenter.org/news/2020/06/17/family-separation-under-trumpadministration-timeline

6. Spagat, E. (2021). Migrant camps grow in Mexico amid uncertainty on US policy. ABC News. https://abcnews.go.com/ International/wireStory/migrant-camps-grow-mexico-amiduncertainty-us-policy-81247591

J Ment Health Soc Behav

Volume 4. 2022. 153
7. Khan, C. (2021). On Mexico's southern border, the latest migration surge is Haitian. National Public Radio. https://www. npr.org/2021/12/18/1065135970/on-mexicos-southern-borderthe-latest-migration-surge-is-haitian

8. Carnevale, P. A., Smith, N., Strohl, J. (2013). Recovery: Job Growth and Education Requirements Through 2020 [Executive Summary]. Georgetown Public Policy Institute, 1-14.

9. Coomans, F. (2018, December 18). Education for migrants: An inalienable human right. UNESCO. https://en.unesco.org/ courier/2018-4/education-migrants-inalienable-human-right

10. Evans, K., Crea, T. M., Chu, Y., Salas-Wright, C. P., Takeuchi, D., Egmont, W., \&Todo-Bom-Mehta, C. (2021). Paths to self-sufficiency for youth served through the unaccompanied refugee minor foster care program in the United States. Journal of International Migration and Integration. https://doi. org/10.1007/s12134-021-00900-7

11. Hao, L., \& Pong, S. (2008). The role of school in the upward mobility of disadvantaged immigrants' children. The ANNALS of the American Academy of Political and Social Science, 620(1), 62-89. doi:10.1177/0002716208322582

12. Naidoo, L. (2009) Developing Social inclusion through afterschool homework tutoring:A study of African refugee students in greater Western Sydney. British Journal of Sociology of Education 30(3): 261-273.

13. Sleijpen, M., Boeije, H., Kleber, R. and Mooren, T. (2016). Between power and powerlessness: A meta-ethnography of sources of resilience in young refugees. Ethnicity \& Health 21(2): 158-180. doi: 10.1080/13557858.2015.1044946

14. Ching, Y., Renes, S. L., McMurrow, S., Simpson, J., \& Strange, A. T. (2017). Challenges facing chinese international students studying in the United States. Educational Research and Reviews, 12(8), 473-482.

15. Kirksey, J. J., Sattin-Bajaj, C., Gottfried, M. A., Freeman, J., \&Ozuna, C. S. (2020). Deportations near the schoolyard: Examining immigration enforcement and racial/ethnic gaps in educational outcomes. AERA Open, 6(1).

16. Szlyk, H. S., Berger Cardoso, J., Lane, L. B., \& Evans, K. (2020). Me perdíaen la escuela: Latino newcomer youth in the U.S. school system.Social Work, 65(2), 131-139. https://doi. org $/ 10.1093 /$ sw $/$ swaa001

17. Weng, S. S., \& Lee, J. S. (2016). Why do immigrants and refugees give back to their communities and what can we learn from their civic engagement? Voluntas 27, 509-524. https://doi. org/10.1007/s11266-015-9636-5

18. DuBois, B., \&Krogsrud Miley, K. (2019). Social work: An Empowering Profession (9th ed.). Pearson.

19. Weick, A. (1992). Building a strengths perspective for social work. In D. Saleebey (Ed.), The strengths perspective in social work practice (pp. 18-26).New York: Longman.

20. Roy,L.A., Roxas, K.C. (2011).Whose deficit is this anyhow? Exploring counter-stories of Somali Bantu refugees' experiences in "doing school". Harvard Educational Review 81(3):521-542. DOI:10.17763/haer.81.3.w441553876k24413

21. Scully, N.J. (2015). Leadership in nursing: The importance of recognising inherent values and attributes to secure a positive future for the profession. 22(4):439-44. doi: 10.1016/j. colegn.2014.09.004.

22. Bernat, V. (2012). Synthesis and application of the first radioligand targeting the allosteric binding pocket of chemokine receptor CXCR3. ChemMedChem, 7(2012),1481-14892. 
23. Ishihara-Brito, R.(2013).Educational Access Is Educational Quality: Indigenous Parents' Perceptions of Schooling in Rural Guatemala.Quarterly Review of Comparative Education 43(2). DOI 10.1007/s11125-013-9263-0

24. Cardoso, J., \& Lane, L. (2016). Practice with immigrant and refugee children and families in the mental health system. In A. Dettlaff \& R. Fong (Eds.), Immigrant and refugee children and families: Culturally responsive practice (pp. 392-427). New York: Columbia University Press.

25. Brenner, M. E., \& Kia-Keating, M. (2017). Psychosocial and academic adjustment among resettled refugee youth. International Perspectives on Education and Society, 30, 221249. doi: https://doi.org/10.1108/S1479-367920160000030016

26. Sullivan, A. L., \& Simonson, G. R. (2016). A systematic review of school-based socialemotional interventions for refugee and war-traumatized youth. Review of Educational Research, 86(2), 503-530. doi: https://doi.org/10.3102/0034654315609419

27. Weaver, H. N. (2016). Between a rock and a hard place: A trauma-informed approach to documenting the traumatic experiences of Tamil refugees. Journal of Human Rights and Social Work, 1, 120-130. doi: https://doi.org/10.1007/s41134016-0013-0

28. Georgis, R, Gokiert, R.J, Ford, D.M and Ali, M (2014) 'Creating inclusive parent engagement practices: lessons learned from a school community collaborative supporting newcomer refugee families.' Multicultural Education, 21 (3-4). pp. 23-27. ISSN 1068-3844.

29. Rah, Y., Choi, S., \& Nguyen, T. S. T. (2009). Building bridges between refugee parents and schools. International Journal of Leadership in Education, 12(4), 347-365. doi: https://doi. org/10.1080/13603120802609867

30. Antony-Newman, M. (2019). Parental involvement of immigrant parents: A meta-synthesis. Educational Review, 71(3), 362-381.

31. Cureton, A. E. (2020). Strangers in the school: Facilitators and barriers regarding refugee parental involvement. The Urban Review, 52(5), 924-949.

32. Schneider, C., \& Arnot, M. (2018). Transactional school-homeschool communication: Addressing the mismatches between migrant parents' and teachers' views of parental knowledge, engagement and the barriers to engagement. Teaching and Teacher Education, 75, 10-20.

33. Silveira, F., Dufur, M. J., Jarvis, J. A., \& Rowley, K. J. (2019). The influence of foreign-born population on immigrant and native-born students' academic achievement. Socius: Sociological Research for a Dynamic World, 5. https://doi. org/10.1177/2378023119845252

34. Suárez-Orozco, C., Gaytán, F. X., HeeJin Bang, Pakes, J., O'Connor, E., \& Rhodes, J. (2010). Academic trajectories of newcomer immigrant youth. Developmental Psychology, 46(3), 602-618. https://doi-org.proxy-bc.researchport.umd. edu/10.1037/a0018201

35. Rodríguez, S., Valle, A., Gironelli, L. M., Guerrero, E., Regueiro, B., \&Estévez, I. (2020b). Performance and well-being of native and immigrant students. Comparative analysis based on PISA 2018. Journal of Adolescence, 85, 96-105. https://doi-org /10.1016/j.adolescence.2020.10.001

36. De Feyter, J. J., Parada, M. D., Hartman, S. C., Curby, T. W., \&Winsler, A. (2020). The early academic resilience of children from low-income, immigrant families. Early Childhood Research Quarterly, 51, 446-461. https://doi-org.10.1016/j. ecresq.2020.01.001
37. Hernandez, D. J., Denton, N. A., Macartney, S., \& Blanchard, V. L. (2012). Children in immigrant families: Demography, policy, and evidence for the immigrant paradox. In C. G. Coll\& A. K. Marks (Eds.), The immigrant paradox in children and adolescents: Is becoming American a developmental risk? (p. 17-36). American Psychological Association. https://doi. org/10.1037/13094-001

38. Crosnoe, R., \& Turley, R. N. L. (2011). K-12 Educational Outcomes of Immigrant Youth. Future of Children, 21(1), 129152. https://doi-org/10.1353/foc.2011.0008

39. Jeong, Y.-J., \&Acock, A. C. (2014). Academic achievement trajectories of adolescents from Mexican and East Asian immigrant families in the United States. Educational Review, 66(2),226-244.https://doi-org/10.1080/00131911.2013.769936

40. Martinez-Taboada, C., Mera, M. J., Amutio, A., Castañeda, X., Felt, E., \&Nicolae, G. (2017). The impact of cultural dissonance and acculturation orientations on immigrant students' academic performance. UniversitasPsychologica, 16(5), 1-14. https:// doi-org/10.11144/Javeriana.upsy16-5.icda

41. Jung, E., \& Zhang, Y. (2016). Parental involvement, children's aspirations, and achievement in new immigrant families. Journal of Educational Research, 109(4), 333-350. https://doiorg/10.1080/00220671.2014.959112

42. Brabeck, K. M., Sibley, E., Taubin, P., \& Murcia, A. (2016). The influence of immigrant parent legal status on U.S.-born children's academic abilities: The moderating effects of social service use. Applied Developmental Science, 20(4), 237-249. https://doi-org/10.1080/10888691.2015.1114420

43. Bowen, G. A. (2009). Document analysis as a qualitative research method. Qualitative Research Journal, 19(2).27-40. https://doi.org/10.3316/QRJ0902027

44. United States Census Bureau. (2021b). Quick facts: [State]. https://www.census.gov/quickfacts/

45. United States Census Bureau. (2021a). Quick facts: [City name masked], United States. https://www.census.gov/quickfacts/

46. U.S. Census Bureau (2019). Selected characteristics of the foreign-born population by period of entry into the united states, American Community Survey. https://data.census.gov/

47. City Public Schools. (2019). [city name] schools: District profile - fall 2019.

48. Gámez, R., Lopez, W., \& Overton, B. (2017). Mentors, resiliency, and ganas: Factors influencing the success of DACAmented, undocumented, and immigrant students in higher education. Journal of Hispanic Higher Education, 16(2), 144-161.

49. Uddin, M. M. (2020). Application of a collective impact model for Latinx Students' access to STEM higher education in Northeast Tennessee Region. Journal of STEM Education: Innovations \& Research, 21(3), 44-49.

50. Akresh, I. R., Massey, D. S., \& Frank, R. (2014). Beyond English proficiency: Rethinking immigrant integration. Social science research, 45, 200-210.

51. Scanlan, M. (2011). Inclusion: How school leaders can accent inclusion for bilingual students, families, \& communities (Bilingual impacts). Multicultural Education, 18(2), 5-9.

52. Espenshade, T. J., \& Fu, H. (1997). An analysis of Englishlanguage proficiency among US immigrants. American Sociological Review, 288-305.

53. Youdelman, M. K. (2008). The medical tongue: US laws and policies on language access. Health Affairs, 27(2), 424-433. 
54. Evans, K., Oliveira, G., Hasson III, R. G., Crea, T. M., Neville, S. E., Fitchett, V. (accepted). Unaccompanied children's education in the United States: Service provider's perspective on challenges and support strategies. Cultura Educación y Sociedad.

55. Potochnick, S. (2018). The academic adaptation of immigrant students with interrupted schooling. American Educational Research Journal, 55(4), 859-892.

56. Office of Refugee Resettlement. (2020). Youth mentoring. https://www.acf.hhs.gov/orr/programs/refugees/youthmentoring

57. Rotich, J. (2011). Mentoring as a springboard to acculturation of immigrant students into American schools. Journal of Case Studies in Education, 1.

58. Cultural Orientation Resource Exchange. (n.d.). Connecting refugee resettlement staff to high-quality Cultural Orientation resources. https://coresourceexchange.org/

59. United Nations High Commissioner for Refugees. (n.d.).Integration handbook: Orientation programs and processes. https://www.unhcr.org/handbooks/ih/placementreception-orientation/orientation-programs-and-processes

60. Rodriguez, S., Roth, B., \& Villarreal Sosa, L. (2020a). School social workers as nepantleras in equity work for immigrant students: A conceptual exploration. Social Service Review, 94(4), 748-780.

61. Şimşek, H., Kurt, D. G., \& Kula, S. S. (2020). A School-based adjustment program based on ecological approach for immigrant students in primary schools living in Turkey. Ilkogretim Online, 19(4), 2551-2563. 10.17051/ilkonline.2020.764622

62. Arizona State University. (n.d.). WeGrad: Accelerate your students' academic success. https://eoss.asu.edu/wegrad

63. Perreira, K. M., Crosnoe, R., Fortuny, K., Pedroza, J. M., Ulvestad, K., Weiland, C., Hirokazu Yoshikawa, H., \&Chaudry, A. (2012). Barriers to Immigrants' Access to Health and Human Services Programs. ASPE Research Brief. Washington, DC: Office of the Assistant Secretary for Planning and Evaluation. http://www.urban.org/publications/413260.html.
64. Yoshikawa, H., Weilans, C., Ulvestad, K., Perreira, K., Crosnoe, R., Chaudry, A., Fortuny, K., Pedroza, J. M. (2014). Improving access of low-income immigrant families to health and human services: The role of community-based organizations. Urban Institute: https://www.urban.org/sites/default/files/ publication/33576/2000011-Improving-Access-of-LowIncome-Immigrant-Families-to-Health-and-Human-Services. pdf

65. Kania, J, \& Kramer, M. (2011). Collective impact. Stanford Social Innovation Review, 9(1), 36-41.

66. Tilhou, R., Eckhoff, A., \& Rose, B. (2021). A collective impact organization for early childhood: Increasing access to quality care by uniting community sectors. Early Childhood Education Journal, 49(1), 111-123. https://doi-org/10.1007/s10643-02001047-3

67. Mkwananzi, F., \&MelisCin, F. (2020). From streets to developing aspirations: How does collective agency for education change marginalised migrant youths' lives? Journal of Human Development and Capabilities, 21(4), 320-338. https://doi-org/10.1080/19452829.2020.1801609

68. The Calgary Bridge Foundation for Youth (2019). Summer bridge program. https://cbfy.ca/2019/08/14/bridge-summerprogram/

69. Bridges to Academic Success. (n.d.). About us. https://bridgessifeproject.com/about-us/

70. Lights Tutoring Center. (n.d.). Immigration bridge for our children. http://www.lightstutoringcenter.com/immigrationbridge-for-our-children/

71. Langenkamp, A. G. (2019). Latino/a immigrant parents' educational aspirations for their children. Race Ethnicity and Education, 22(2), 231-249.

72. Wilder Research Foundation. (2009). Parent involvement in school: Engaging immigrant parents. https://files.eric.ed.gov/ fulltext/ED511597.pdf 